\title{
A Study on Socio Economic Profile of ATMA Respondents
}

\author{
Pankaj Kumar Mandal" and B. Jirli \\ Department of Extension Education, Institute of Agricultural Sciences, BHU, India \\ *Corresponding author
}

\section{Keywords}

Socio economic profile, ATMA, Agri-enterprise

Article Info

Accepted:

06 September 2018

Available Online:

10 October 2018

\section{A B S T R A C T}

In Bihar, Agricultural Technology Management Agency (ATMA) were registered as an autonomous institution and operationalized in four districts viz., Muzaffarpur, Madhubani, Munger and Patna districts in year1999, 2000, 2001 and 2002 respectively across the State. ATMA programme at present under implementation in all the 38 districts of the state. The ATMA programme several strategies followed such as mobilization of farmers and farm women are organised into FIGs/SHGs, providing them training on new technology and promoting them to start their own agri-enterprise. The sample was of 260 respondents of which all were received training on cultivation of rice, wheat and potato. Study reveals that $(93.5 \%)$ of the respondents were male and $(6.5 \%)$ female. The maximum number of respondents $(63.5 \%)$ belonged to 41 to 57 years age group. The maximum numbers of respondents $(52.7 \%)$ were engaged in farming as a sole profession and only $(4.6 \%)$ were service and farming. Majority of the respondents $(84.2 \%)$ were literates whereas Illiterates were noticed to the extent of 15.8 per cent. The maximum numbers of respondents $(64.6 \%)$ were marginal farmers having land holding less than 1 hectare. The maximum numbers of respondents $(63.5 \%)$ were possessed farm power and only $(36.5 \%)$ were having not possessed any farm power. The maximum numbers of respondents had $(71.9 \%)$ belonged to nuclear family and $(28.1 \%)$ of the respondents had belonged to joint family. The maximum numbers of respondents (54.6\%) were having up to 5 family size and (76.2\%) had family annual income ₹131168 - ₹261970.

\section{Introduction}

The Indian agriculture is at the turning point today. The agricultural growth has powerful leverage effects on the rest of the economy and all the three basic objectives of economic development of the country, viz. poverty alleviation, output growth, and price stability is best contribute by the growth of the agricultural sector (Agnihotri et al., 2018). Agricultural Technology Management Agency (ATMA) is a registered society responsible for more effective and efficient dissemination of available agricultural technologies at district level.

It has linkage with the extension-related activities of ICAR institutes, including KVKs, research organizations line departments, NGOs and the private sector associated with agricultural development at the district and block levels (DAC, 2010). The Agricultural Technology Management Agency (ATMA) is the flagship programme for agricultural 
extension reforms in India. Agricultural technology management agency (ATMA) at district level was pilot tested under innovations in technology dissemination (ITD) component of World Bank funded national agricultural technology project (NATP) with effect from November, 1998 to 2004.

It was implemented as a pilot in seven states viz., Andhra Pradesh, Maharashtra, Bihar, Himachal Pradesh, Jharkhand, Orissa and Punjab covering 4 districts in each state from 1998 to 2005 as part of the World Bankfunded Innovations in Technology Dissemination (ITD) component of the National Agriculture Technology Project (NATP) (Sahu et al., 2013).

In Bihar, Agricultural Technology Management Agency (ATMA) were registered as an autonomous institution and operationalized in four districts viz., Muzaffarpur, Madhubani, Munger and Patna districts in year 1999, 2000, 2001 and 2002 respectively across the State. ATMA programme at present implementation in all the 38 districts of the state. The primary operational bodies of ATMA are found at the district and block levels (Simpson et al., 2013).

In Bihar, under ATMA programme several strategies followed such as mobilization of farmers and farm women are organised into FIGs/SHGs, providing them training on new technology and promoting them to start their own agri-enterprise (Singh and Singh, 2014).

De and Jirli (2005) reported in his lead paper that social impact as change that occur in peoples' way of life (how they live, work, play and interact with one another on a day to day basis), their culture (shared beliefs, customs and values) and their community (its cohesion, stability, character, services and facilities). This change may involve significant impacts experienced by people as result of development. Socio-economic status is a combined measurement of economic and social position of an individual or a group in relation to others in the society. It has a profound role in determining one's accessibility to the common resources, livelihood pattern, household food \& nutritional security etc (Roy et al., 2013). The present study was undertaken with a specific objective to study the socio economic profile of ATMA respondents.

\section{Materials and Methods}

This study was carried out in Madhubani district of Bihar state. Madhubani district has been divided into twenty one (21) blocks. Out of the twenty one blocks of Madhubani district, four (4) blocks namely Rajnagar, pandaul, Jhanjharpur and Madhepur were selected randomly and from each block five villages were randomly selected for the study. From each village $30 \%$ respondents were selected randomly, who received training on cultivation of rice, wheat and potato under ATMA programme thus total sample size of 260 respondents. The obtained results were analyzed in the form of frequency and percentage.

\section{Results and Discussion}

The socio-economic attributes of the respondents were studied in terms of their gender, age distribution, caste, occupation, education, size of land holding, farm power family size, family type, annual income. The frequency and per cent distribution of respondents for each selected independent variable has been presented here separately.

Agriculture is not limited to any particular sex; both male and female can participate actively depending on the asset each possesses. 
From the Table 1 it is observed that Majority of $(84.2 \%)$ of the respondents were male while $(15.8 \%)$ were female. Thus it can be concluded that involvement in ATMA programme and agriculture activities mostly dominated by men and least involved by females due there are some factors that hinder female active participation in ATMA programme and agriculture

The age structure of the farmers is an essential factor in the perspective of agricultural production or productivity and acceptance behaviour regarding new technology.

From above Table 2 reveals that majority of the respondents $(63.50 \%)$ belonged to 41 to 57 years age group followed by 58 years age group \& above $(20.8 \%)$ and Up to 40 years age group (15.8\%).

Thus, it may be concluded that majority of respondents belongs to 41 to 57 years age. This finding might be due to reason that 41 to 57 years age group people were more actively participated in ATMA programme and agricultural activities.

Caste is a social class which is determined by birth, involves particular ritual, restriction and freedom.

From above Table 3 showed that majority of respondents $(41.9 \%)$ belonged to general category followed by other backward category $(31.2 \%)$, EBC category (18.8\%), only $(1.16 \%)$ of respondents belonged to Scheduled caste and scheduled tribal category. Thus, it may be concluded that majority of the respondents belonged to general caste followed by other backward caste, extremely backward caste and least scheduled caste and scheduled tribes. This finding might be due to reason that maximum population of general categories and least scheduled caste and scheduled tribes in study area.
Occupation is an important socio-economic attribute that determining family's livelihood, level of income. Farmers engage in multiple jobs to ensure income to their family.

From above Table 4 indicates that majority of the respondents $(52.7 \%)$ were engaged in farming as a sole profession followed by business and farming $(26.5 \%)$, caste based profession and farming $(9.2 \%)$ and labour and farming $(6.9 \%)$, only $(4.6 \%)$ were service and farming. Thus, it may be concluded that majority of the respondents were engaged in farming as a sole profession.

This finding might be due to the reason that larger number population totally dependent on agriculture and agriculture allied like beekeeping, horticulture, livestock etc.

Education is one of the important factors of socio-economic that indicated the social status of persons' family or society. Education of farmers plays a vital role in successful acceptance of modem technology and farming practices. Hence educational of farmers is a key factor in the process of production.

From above Table 5 showed that majority of the respondents $(25.5 \%)$ were high school education followed by intermediate education (21.2\%), middle school (18.1\%), primary school education $(13.5 \%)$, only graduate and above level education (6.2\%).

Illiterates were noticed to the extent of 15.8 per cent. Thus, it may be concluded that majority of the respondents were completed high school education. This finding might be due to the reason that lack of college and lack of awareness about higher education.

Land is an important income generating asset of farmers. The economic status of the farmers depends upon the size of land holding possession. 
Table.1 Distribution of respondents according to their gender

\begin{tabular}{|c|l|l|l|}
\hline SI. No. & Category & Frequency & Percentage \\
\hline 1 & Male & 243 & 93.5 \\
\hline 2 & Female & 17 & 6.5 \\
\hline & Total & 260 & 100.0 \\
\hline
\end{tabular}

Table.2 Distribution of respondents according to their age

\begin{tabular}{|c|l|l|l|}
\hline SI. No. & Category & Frequency & Percentage \\
\hline 1 & Up to 40 years age & 41 & 15.8 \\
\hline 2 & 41 to 57 years age & 165 & 63.5 \\
\hline 3 & 58 years age \& above & 54 & 20.8 \\
\hline \multicolumn{2}{r|}{ Total } & 260 & 100.0 \\
\hline
\end{tabular}

Mean $=49.35 \mathrm{SD}=8.54$

Table.3 Distribution of respondents according to their caste category

\begin{tabular}{|c|l|l|l|}
\hline Sl. No. & Category & Frequency & Percentage \\
\hline $\mathbf{1}$ & General & 109 & 41.9 \\
\hline $\mathbf{2}$ & OBC & 81 & 31.2 \\
\hline $\mathbf{3}$ & EBC & 49 & 18.8 \\
\hline $\mathbf{4}$ & SC/ ST & 21 & 8.1 \\
\hline
\end{tabular}

Table.4 Distribution of respondents according to their occupation

\begin{tabular}{|c|l|l|l|}
\hline Sl. No. & Category & Frequency & Percentage \\
\hline 1 & Farming as a sole profession & 137 & 52.7 \\
\hline 2 & Caste based profession + Farming & 24 & 9.2 \\
\hline 3 & Business + Farming & 69 & 26.5 \\
\hline 4 & Service + Farming & 12 & 4.6 \\
\hline 5 & Labour and Farming & 18 & 6.9 \\
\hline & Total & 260 & 100.0 \\
\hline
\end{tabular}

Table.5 Distribution of respondents according to their level of education

\begin{tabular}{|c|l|l|l|}
\hline S. No. & Category & Frequency & Percentage \\
\hline $\mathbf{1}$ & Illiterate & 41 & 15.8 \\
\hline $\mathbf{2}$ & Primary school & 35 & 13.5 \\
\hline $\mathbf{3}$ & Middle school & 47 & 18.1 \\
\hline $\mathbf{4}$ & High school & 66 & 25.4 \\
\hline $\mathbf{5}$ & Intermediate & 55 & 21.2 \\
\hline $\mathbf{6}$ & Graduate and above level & 16 & 6.2 \\
\hline & $\quad$ Total & $\mathbf{2 6 0}$ & $\mathbf{1 0 0 . 0}$ \\
\hline
\end{tabular}


Table.6 Distribution of respondents according to their size of land holding

\begin{tabular}{|c|l|l|l|}
\hline SI. No. & Category & Frequency & Percentage \\
\hline $\mathbf{1}$ & Marginal Farmer (below to1 ha) & 168 & 64.6 \\
\hline $\mathbf{2}$ & Small Farmer (1-2 ha) & 76 & 29.2 \\
\hline 3 & Semi-medium Farmer (2-4 ha) & 12 & 4.6 \\
\hline 4 & Medium Farmer (4-10 ha) & 04 & 1.5 \\
\hline 5 & Large Farmer (above 10 ha) & 00 & 00 \\
\hline & Total & 260 & 100.0 \\
\hline
\end{tabular}

Table.7 Distribution of farmers according to their farm power

\begin{tabular}{|c|l|l|l|}
\hline SI. No. & \multicolumn{1}{|c|}{ Category } & Frequency $^{*}$ & Percentage \\
\hline $\mathbf{1}$ & Bullock & 14 & 5.4 \\
\hline $\mathbf{2}$ & Diesel Pumping set & 75 & 28.4 \\
\hline $\mathbf{3}$ & Electric motor & 31 & 11.9 \\
\hline $\mathbf{4}$ & Power Tiller & 24 & 9.2 \\
\hline $\mathbf{5}$ & Thresher & 19 & 7.3 \\
\hline $\mathbf{6}$ & Tractor & 41 & 15.8 \\
\hline $\mathbf{7}$ & No farm power & 95 & 36.5 \\
\hline
\end{tabular}

*Multiple responses

Table.8 Distribution of respondents according to their type of family

\begin{tabular}{|c|l|l|l|}
\hline SI. No. & Category & Frequency & Percentage \\
\hline 1 & Nuclear family & 187 & 71.9 \\
\hline 2 & Joint family & 73 & 28.1 \\
\hline \multicolumn{1}{|c|}{ Total } & 260 & 100.0 \\
\hline
\end{tabular}

Table.9 Distribution of respondents according to their size of family

\begin{tabular}{|c|l|l|l|}
\hline S. No. & Category & Frequency & Percentage \\
\hline 1 & Up to 5 family members & 142 & 54.6 \\
\hline 2 & 6 to 9 family members & 67 & 25.8 \\
\hline 3 & 10 family members \& above & 51 & 19.6 \\
\hline \multicolumn{2}{r}{ Total } & 260 & 100.0 \\
\hline
\end{tabular}

Mean=7.26 SD=2.58

Table.10 Distribution of respondents according to their family annual income

\begin{tabular}{|c|l|l|l|}
\hline SI. No. & Category & Frequency & Percentage \\
\hline $\mathbf{1}$ & Up to Rs 131167 & 17 & 6.5 \\
\hline $\mathbf{2}$ & Rs 131168 to 261970 & 198 & 76.2 \\
\hline Rs 261971 \& above & Total & 45 & 17.3 \\
\hline
\end{tabular}

Mean=196569 SD=65401.47 
The data presented in Table 6 inferred that majority of respondents (64.6\%) were marginal farmers having land holding less than 1 hectare followed by small farmers (29.2\%) having land holding 1-2 hectare, Semi-medium farmers (4.6\%) having land holding 2-4 hectare, only (1.5\%) belonged to medium farmers with land holding of 4-10 hectare of land. None of the respondents was found in large farmers. Thus, it may be concluded that majority of the respondents were having marginal farmers. This finding might be due to the reason that fragmented of land among the family members because of most of family were nuclear family in study area.

Farm Power is an important input in agriculture for timely doing farm work and increasing production and productivity of land.

From above Table 7 reveals that that majority of respondents $(28.5 \%)$ were possessed diesel Pumping set followed by tractor (15.8\%), electric motor $(11.9 \%)$, power tiller $(9.2 \%)$, thresher (7.3\%), and Bullock (5.4\%) respectively. Most of respondents (36.5\%) were having not possessed any farm power. Thus, it may be concluded that majority of the respondents were having not possessed any farm power. This finding might be due to the reason that high cost of farm power machinery. The income levels of respondents were low so they not afford farm power.

The family is an important primary group in a society. It is the simplest and the most elementary form of society. Type of family plays a vital role in decision making process and economic activity in family.

The result from Table 8 indicated that majority of respondents had (71.9\%) belonged to nuclear family and $(28.1 \%)$ of the respondents had belonged to joint family.
Thus, it may be concluded that majority of the respondents were belonged to nuclear family followed by joint family. This finding might be due to the reason that joint family system disintegrated over a period of time in study area.

Family size plays an important role in determining the Participation in farm activities and economic behaviour of the family regarding income and expenditure. Size of family also determines the provision of family labour in agricultural sector.

From above Table 9 reflected that majority of the respondents $(54.6 \%)$ were having up to 5 family members size followed by 6 to 9 family members size (25.8\%) and 10 family members size \& above (19.6\%). Thus, it may be concluded that majority of the respondents were having up to 5 family members. This finding might be due to the reason that most respondents belonged to nuclear family.

Income is one of most important yardstick measuring the economic conditions of the farmers. A farmer earns its incomes from various sources like agricultural activities, non-agricultural activities, wage and salaries, etc.

From above Table 10 showed that majority of the respondents $(76.2 \%)$ had family annual income between ₹131168 - ₹261970 followed by ₹ $261971 \&$ above $(17.3 \%)$, and $(6.5 \%)$ of respondents had family annual income up to₹ 131167. Thus it can be concluded that that majority of the respondents per had family annual income between ₹131168 - ₹261970 followed by 17.3 per cent respondents $₹$ $261971 \&$ above and 6.5 per cent of respondents up to₹ 131167. This finding might be due to the reason that most of respondent having marginal framer and mostly dependent on agriculture. 
The study revealed that maximum number of ATMA respondents men, belonged to 41 to 57 years age group and nuclear family, engaged in farming as a sole profession, literates, marginal farmers, possessed farm power, having up to 5 family members size and family annual income ₹131168 - ₹261970 in study area. Involvement in ATMA programme activities mostly dominated by men and least involved by females due there are some factors that hinder female active participation in ATMA programme, so need to increase involvement of female in ATMA programme activities in study area.

\section{References}

Agnihotri, N., Bose D.K and Jahanara (2018) Adoption of sugarcane production technologies by its beneficiaries and non-beneficiaries through ATMA programme in Sitapur district of Uttar Pradesh. Journal of Pharmacognosy and Phytochemistry, 7(3): 3642-3644.

DAC (Department of Agriculture and Cooperation) (2010) Guidelines for Modified Support to State Extension Programmes for Research and Extension Reforms Scheme, 2010,
Department of Agriculture and Cooperation, Ministry of Agriculture, Government of India, June 2010.

De, D and Jirli, B. (2005) Impact assessment: concepts, domains and phraseology. National seminar.

Roy, M.L., Chandra, N., Kharbikar, H.L., Joshi, P., Jethi, R. (2013) Socioeconomic Status of Hill Farmers: An Exploration from Almora District in Uttarakhand. International Journal of Agriculture and Food Science Technology, 4(4):353-358.

Sahu, B. P., Chaturvedi, M.K. and Yadaw, K. N. (2013) Impact of agricultural technology management agency (ATMA) on socio-economic status of tribal farmers. Agric. Update, 8(1\&2): 1-7.

Simpson, B. M., Singh, K. M and Singh, A. (2013) Strengthening the pluralistic agricultural extension system in Bihar State, India, report on the MEAS Rapid Scoping Mission.

Singh, D.K. and Singh, P. (2014) Effectiveness of Training Programmes under Agricultural Technology Management Agency in Bihar, Indian Res. J. Ext. Edu. 14(1): 93-95.

\section{How to cite this article:}

Pankaj Kumar Mandal and Jirli, B. 2018. A Study on Socio Economic Profile of ATMA Respondents. Int.J.Curr.Microbiol.App.Sci. 7(10): 619-625. doi: https://doi.org/10.20546/ijcmas.2018.710.069 